Original Article

\title{
QUANTITATIVE ASSAY OF ASPIRIN AND (SALICYLIC ACID AND HEAVY METALS AS IMPURATIES) IN IRAQI'S MARKET ASPIRIN TABLETS USING DIFFERENT ANALYTICAL METHODS
}

\author{
AHMED MAHDI SAEED ${ }^{*}$, MOHAMMED JASSIM HAMZAH ${ }^{2}$, NOOR QASIM AHMED ${ }^{1}$ \\ ${ }^{1}$ Chemistry Department, College of Education for Pure Science, Diyala University, Iraq, ${ }^{2}$ Pharmaceutical Chemistry Department, Pharmacy \\ College, Al-Nahrain University, Iraq \\ Email: dr.ahmedalanbakey@yahoo.com
}

Received: 09 May 2018, Revised and Accepted: 20 Jul 2018

\section{ABSTRACT}

Objective: Easy and precise methods were developed for estimation of aspirin (ASP), impurities from such as salicylic acid (SAL) and heavy metal ions (HMI) in ASP tablets that available in the Iraqi's market using High-performance liquid chromatography (HPLC), UV-VIS spectrophotometry and atomic absorption spectrophotometric (AAS).

Methods: HPLC separation was carried out using C18 as stationary phase and acetonitrile (ACN): water in the ratio of (10: 90 v/v) as a mobile phase for HPLC method and as a solvent for UV-VIS spectrophotometric for quantitative ASP and SAL at $254 \mathrm{~nm}$ for HPLC, 226 and $296 \mathrm{~nm}$ for UV measurements. AAS was used for HMI determination.

Results: ASP and SAL gave absorbance maxima at 226 and $296 \mathrm{~nm}$ in ACN: $\mathrm{H}_{2} \mathrm{O}$ solvent. The Beer's law was obeyed in the range of $0.05-20$ for ASP and $0.02-8 \mu \mathrm{g} / \mathrm{ml}$ for SAL. Correlation coefficients $\left(\mathrm{R}^{2}\right)$ were 0.9996 and 0.9992 for ASP and SAL respectively, for HPLC and LOD value was 0.006 for ASP and $0.004 \mu \mathrm{g} / \mathrm{ml}$ for SAL. The \% recovery for the developed method was found to be in the range of ( 98.80 to $101.26 \%$ ) and ( 98.67 to $103.33 \%$ ) for ASP and SAL respectively, within the acceptable range, that approved by world health organization (WHO).

Conclusion: The proposed method can help research studies, quality control and routine analysis with lesser resources available. The results of the assay of pharmaceutical formulation of the developed method are highly reliable and reproducible and is in good agreement with the label claim of the medicines.

Keywords: HPLC, Salicylic acid, Heavy metals, Aspirin tablets

(C) 2018 The Authors. Published by Innovare Academic Sciences Pvt Ltd. This is an open access article under the CC BY license (http://creativecommons.org/licenses/by/4.0/) DOI: http://dx.doi.org/10.22159/ijap.2018v10i5.26820

\section{INTRODUCTION}

In HPLC method there are several factors such as, the interaction between the solute components and the stationary phase that affected the chromatography resolution. HPLC is a good method for analysis of drugs because it has good selectivity and sensitivity values with small levels and in a complex matrix [1]. Therefore, the HPLC systems can be easily used to separate a wide range of chemical components. ASP is a nonsteroidal anti-inflammatory, antirheumatic, antithrombotic; chemically it is 2-acetoxy benzoic acid (fig. 1a) [2, 3]. In addition, aspirin is broadly used for the treatment of fever, inflammatory diseases, pain and blood thinner to prevent blood clots [4]. ASP is rapidly hydrolyzed in the body to produce salicylic acid (fig. 1b), which is the compound that is primarily responsible for the pharmacological activity of ASP. SAL is further metabolized to gentisic acid, salicyluric acid and other conjugates. It is not therapeutically active molecule as compare with ASP [5].<smiles>CC(=O)Oc1ccccc1C(=O)O</smiles>

a

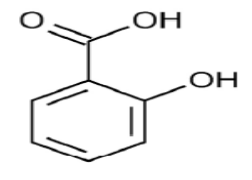

b
Fig. 1: Chemical structure of aspirin and salicylic acid

An impurity in a drug substance as defined by the International Conference on Harmonisation (ICH) Guidelines, is any component of the drug substance that is not the chemical entity defined as the drug substance and affects the purity of active ingredient or drug substances [6]. The impurity profile of pharmaceuticals is of increasing importance as drug safety receiving more and more attention from the public and from the media. Therefore, identification, quantification, and control of impurities in the drug substance and drug product, are an important part of drug development and regulatory assessment [7]. Some evidences revealed that HPLC in particular mobile phase method was used to measure ASP and SAL in dosage forms or in biological materials [812]. The aim of this work is to develop a new analytical method, which consider to be an easy and applicable method to measure ASP and impurities in the aspirin tablets which are commercially available in Iraqi market pharmacy.

\section{MATERIALS AND METHODS}

\section{Reagents and chemicals}

ASP and SAL as pure standard powders were supplied by Sammara Drug Industries (SDI) Iraq. ASP tablets were obtained from local market. Acetonitrile (ACN), Methanol (HPLC-grade) and heavy metal ion solutions (AAS-grade) were from BDH. All chemicals and reagents were of analytical grade and double distilled water was used.

\section{Instrumentation and analysis condition}

Spectroscopic analysis was carried out using Jasco V-650 Japan double beam UV-Visible spectrophotometer with $10 \mathrm{~mm}$ path length quartz cells was used for the analytical purpose. The separation was achieved by using HPLC Shimadzu LC-20 A, Japan uses ACN: $\mathrm{H}_{2} \mathrm{O}$ (10: 90) as mobile phase and Phenomenex C18 column $(50 \times 4.6$ $\mathrm{mm}, 3 \mu \mathrm{m}$ ). The separation was monitored for $5 \mathrm{~min}$ at $254 \mathrm{~nm}$ using a UV-visible detector and $1 \mathrm{ml} / \mathrm{min}$ flow rate. Atomic absorption AUORA Canadian model was used for HMI analysis.

Preparation of stock solutions of drugs $(100 \mu \mathrm{g} / \mathrm{ml})$

Accurately weighed $0.01 \mathrm{~g}$ pure samples of ASP and SAL were transferred to $100 \mathrm{ml}$ calibrated volumetric flask, dissolved and made 
up to the mark with ACN: $\mathrm{H}_{2} \mathrm{O}$ (10: $90 \mathrm{v} / \mathrm{v}$ ). It was the stock solution of ASP and SAL $(100 \mu \mathrm{g} / \mathrm{ml})$ in $\mathrm{ACN}$ : $\mathrm{H}_{2} \mathrm{O}$. By using the stock solution of $100 \mu \mathrm{g} / \mathrm{ml}$, subsequent dilution was carried out by withdrawing different aliquots $(0.02-3.0 \mathrm{ml})$ from standard solution were transferred into a series of $10 \mathrm{ml}$ calibrated volumetric flasks and all were made up to the mark with ACN: $\mathrm{H}_{2} \mathrm{O}$ in order to prepare working standard solutions of different concentrations $(0.02-30 \mu \mathrm{g} / \mathrm{ml})$.

\section{Procedure for drugs assay in pharmaceuticals tablets}

Ten tablets of ASP drug's formula were weighed accurately and powdered finely. An accurately weighed quantity of tablets, powder equivalent to $100 \mathrm{mg}$ of ASP was transferred to a $100 \mathrm{ml}$ volumetric flask and diluted with $\left(\mathrm{H}_{2} \mathrm{O}:\right.$ ACN 90: $\left.10 \mathrm{v} / \mathrm{v}\right)$, and the content was ultrasonicated for $20 \mathrm{~min}$. The volume was made up to the mark with solvent and mixed well. The solutions were further filtered using whatman no. 1 filter paper to remove any unwanted particulate materials. The filtered solutions were further appropriately diluted with a respective solvent to finally produce a sample solution of concentration $10 \mu \mathrm{g} / \mathrm{ml}$ for analysis. The amount of ASP, SAL and heavy metal ions present in the sample solution was determined by using the calibration graphs of the standard.

\section{RESULTS AND DISCUSSION}

\section{UV-VIS Spectrophotometry method}

\section{Estimation of detection wavelength}

A solution of ASP and SAL mixture in the concentration of $10 \mu \mathrm{g} / \mathrm{ml}$ was scanned in the range of wavelength $200-400 \mathrm{~nm}$ [13]. It was observed that the ASP and SAL mixture showed considerable absorbance at a wavelength of 226 and $296 \mathrm{~nm}$. The absorption spectrum was found sharp and maximum at a wavelength of $226 \mathrm{~nm}$ for ASP and at $296 \mathrm{~nm}$ for SAL. Therefore, it was selected as the wavelength for detection in $\left(\mathrm{H}_{2} \mathrm{O}: \mathrm{ACN}\right.$ 90: $\left.10 \mathrm{v} / \mathrm{v}\right)$. The study of spectrum revealed that ASP and SAL mixture shows a well-defined $\lambda_{\max }$ at 226 and $296 \mathrm{~nm}$ respectively as shown in (fig. 2).

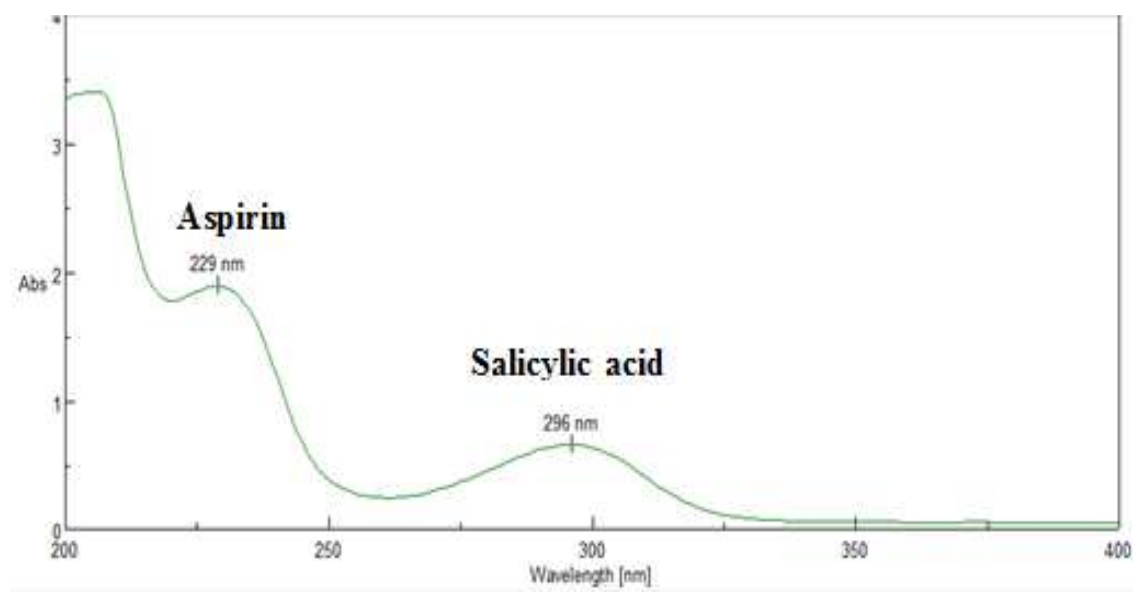

Fig. 2: UV-VIS spectrum of aspirin and salicylic acid mixture

\section{Preparation of calibration graphs}

The solutions of ASP and SAL standard mixture in different concentrations (0.05 to 30 and 0.02 to $8 \mu \mathrm{g} / \mathrm{ml}$ ) for ASP and SAL respectively, were taken and the absorbance of these solutions were measured against solvent $\left(\mathrm{H}_{2} \mathrm{O}: \mathrm{ACN}\right.$ 90: $\left.10 \mathrm{v} / \mathrm{v}\right)$ as blank at a wavelength of $229 \mathrm{~nm}$ and $296 \mathrm{~nm}$. A calibration graphs were constructed by plotting absorbance versus concentrations and a regression equations were calculated [14]. From the calibration graphs, it was found that ASP and SAL obeys Beer's law in concentrations of $0.3-30$ and $0.1-10 \mu \mathrm{g} / \mathrm{ml}$ for ASP and SAL respectively, as shown in (fig. 3). Statistical parameters were calculated as shown in (table 1), revealed that the $t_{\text {cal }}$ values were larger than the values of $t_{\text {tab. }}$. Good linearity was observed with an $\mathrm{R}^{2}$ of (0.9996 and 0.9992) for ASP and SAL respectively. The linear regression data for the calibration plot are indicative of a good linear relationship between concentration variation and response. Determined of linearity was done by regression analysis.

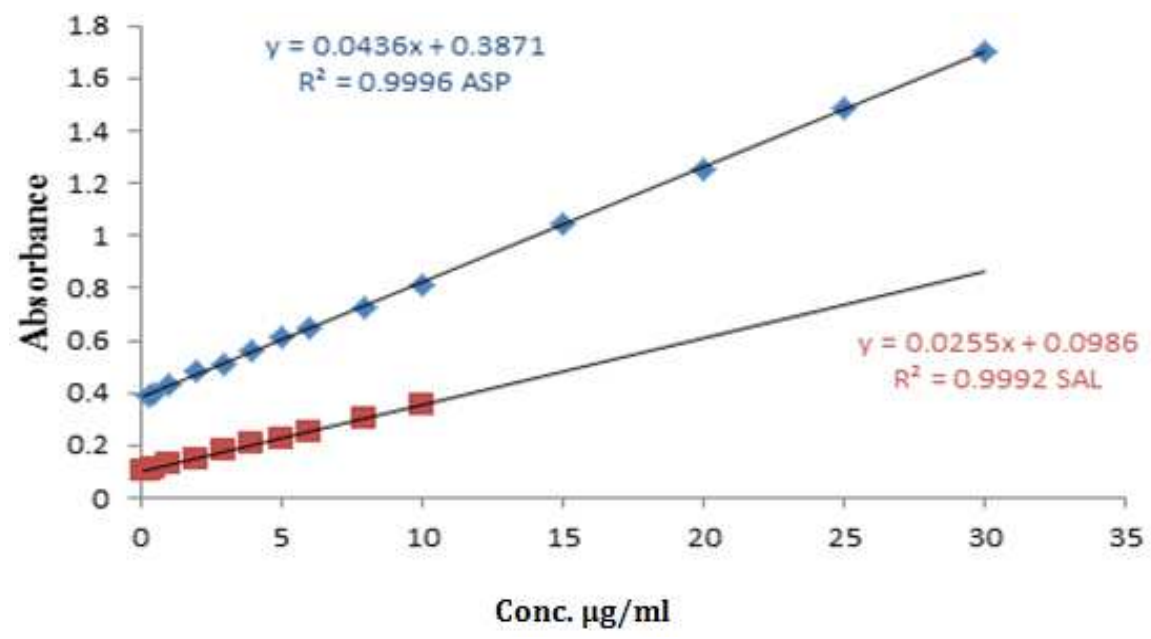

Fig. 3: UV-VIS calibration graphs of ASP and SAL mixture 
Table 1: Statistical parameters of UV-VIS determination of ASP and SAL

\begin{tabular}{lll}
\hline Statistical parameter & Value & Salicylic acid \\
\cline { 2 - 3 } & Aspirin & $\mathrm{y}=0.0255[\mathrm{X}]+0.0986$ \\
\hline Linear equation & $\mathrm{y}=0.0436[\mathrm{X}]+0.3871$ & 0.0255 \\
Slope $(\mathrm{m})$ & 0.0436 & 0.0986 \\
Intercept (b) & 0.3871 & 0.9992 \\
Correlation Coefficient $\left(\mathrm{R}^{2}\right)$ & 0.9996 & 99.92 \\
Percentage Linearity (R ${ }^{2}$ ) & 99.96 & 0.13 \\
Intercept standard error & 0.22 & 0.18 \\
Intercept standard deviation & 0.33 & 1.12 \\
Relative standard deviation (RSD) & 1.41 & 0.03 \\
LOD ( $\mu \mathrm{g} / \mathrm{ml})$ & 0.09 & $0.1-10$ \\
Linearity range $(\mu \mathrm{g} / \mathrm{ml})$ & $0.3-30$ & $106.04>>2.21$ \\
Calculated t-value & $173.7>>2.14$ & \\
\hline
\end{tabular}

\section{HPLC method}

\section{Chromatographic condition}

The RP-HPLC method was developed to provide specific procedure for the rapid quality control analysis of ASP and SAL. To find the appropriate HPLC condition for the separation of the examined drugs, various reversed-phase columns, isocratic mobile phase systems and different wavelength detection were tried and successfully attempts were performed using a Phenomenex C18 column $(50 \times 4.6 \mathrm{~mm}, 3 \mu \mathrm{m})$ and a mobile phase composed of $\mathrm{ACN}: \mathrm{H}_{2} \mathrm{O}$ (10: 90) at a flow rate of 1 $\mathrm{ml} / \mathrm{min}$ with $\lambda_{\max }$ at $254 \mathrm{~nm}$. Injection volume was $20 \mu \mathrm{l}$ and elution time was close to five min. various analytical columns were tested for obtaining good and reproducible response within the short run time. Under the described HPLC parameters, the respective compound was

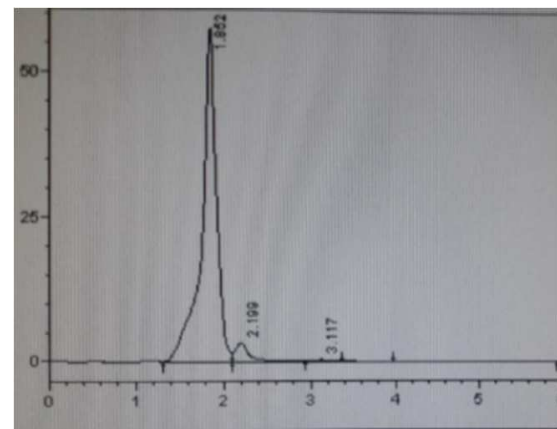

(a): Mixture on C 18 column at $254 \mathrm{~nm}$

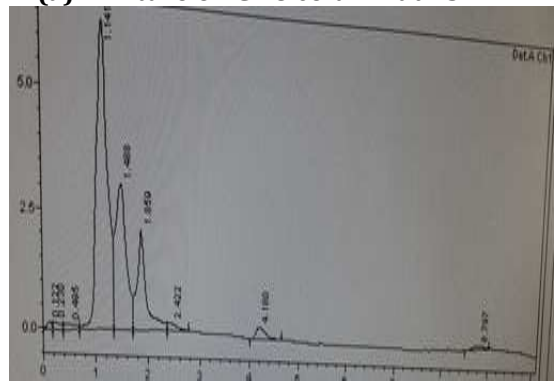

(c): Mixture on C 18 column at $214 \mathrm{~nm}$

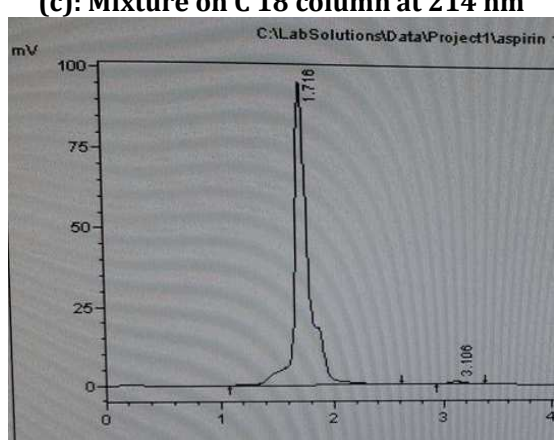

(e): ASP on C 18 using $10 \%$ ACN at 254 nm clearly separated and their typical chromatogram (fig. 4a), which shows a clear separation between the peaks at reasonable Rt 1.8 and 2.199 min using a C18 column in comparison with C8, which shows Rt higher than 2.199 and unclear chromatogram (fig. 4 b). Three selected detector wavelengths $(254,214$ and $270 \mathrm{~nm})$ were applied to estimate the separated compounds chromatograms as shown in (fig. 4 a, c and d). The results were indicated that the best chromatogram was obtained at $254 \mathrm{~nm}$. HPLC separation of ASP and SAL had been carried out using various mobile phases consisting of water and (methanol or acetonitrile) as the organic phase. Fig. 4 (e, f and g) are shown the chromatograms of ASP and SAL standard analysis on C18 at $254 \mathrm{~nm}$ using different mobile phase ACN: $\mathrm{H}_{2} \mathrm{O}$ and methanol: $\mathrm{H}_{2} \mathrm{O}$, which shown more Rt than 1.8 and it means that developed method is more rapid.

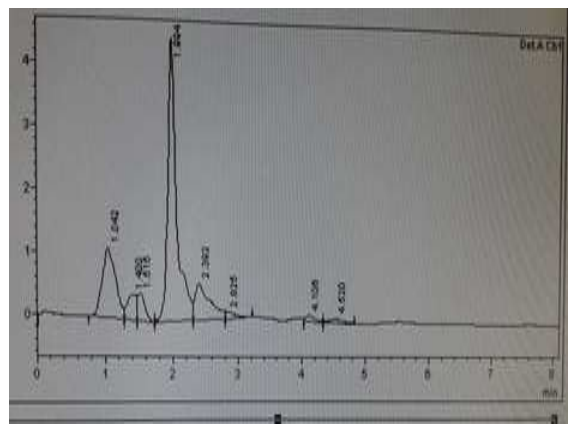

(b): Mixture on C 8 column at $254 \mathrm{~nm}$

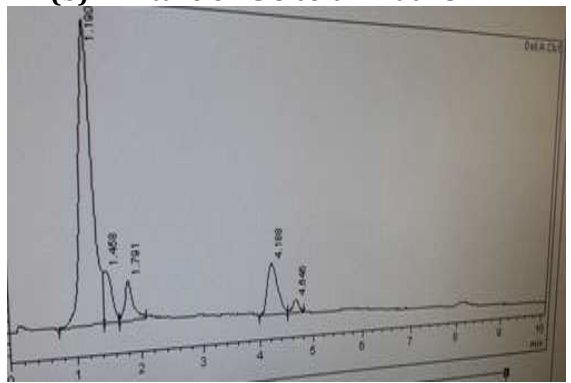

(d): Mixture on C 18 column at $270 \mathrm{~nm}$

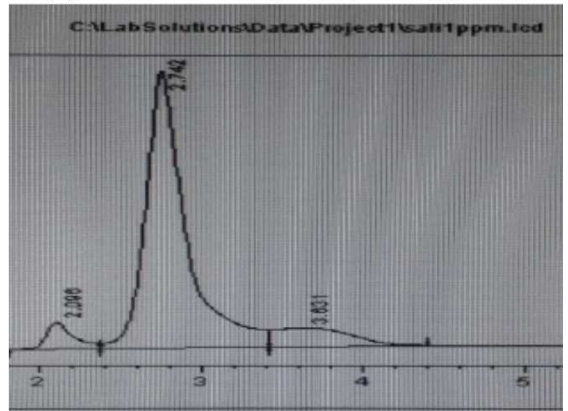

(f): SAL on C 18 using $10 \%$ ACN at $254 \mathrm{~nm}$ 


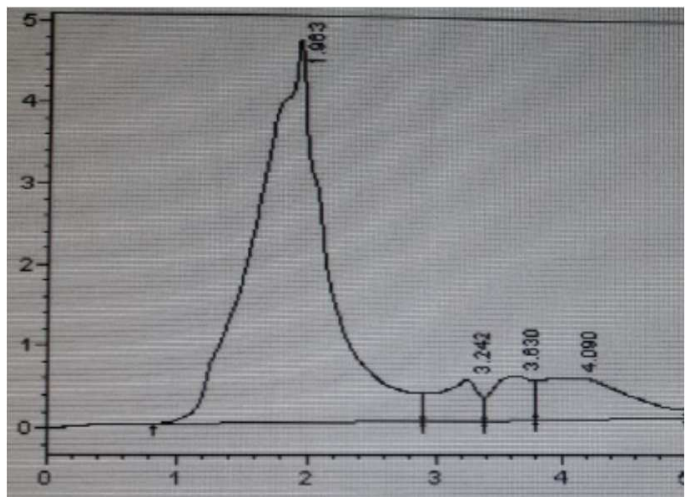

(g): ASP on C 18 using $10 \%$ methanol at $254 \mathrm{~nm}$

Fig. 4 (a-g): Chromatograms of ASP, SAL and mixture using different condition

\section{HPLC calibration graphs}

Calibration graph representing the relation between the concentrations of drugs versus the peak area was constructed. A 20 $\mu \mathrm{l}$ of the standard solutions contain ASP or SAL were injected in triplicate run from which the linear regression equation was calculated. A calibration graphs were constructed by plotting area under peak versus concentrations and a regression equations were calculated. The results of chromatographic determination are presented in table 2, which shown that the linear dynamic range for aspirin was in the range $0.05-20 \mu \mathrm{g} / \mathrm{ml}$, while for salicylic acid was $0.02-8 \mu \mathrm{g} / \mathrm{ml}$ as shown in (fig. 5). The statistical analytical values such as correlation coefficient $\left(\mathrm{R}^{2}\right)$, limit of detection (LOD) and other parameters for HPLC methods were tabulated in table 2. Good linearity was observed with an $\mathrm{R}^{2}$ of $(0.9993$ and 0.9992$)$ for ASP and SAL respectively. The linear regression data for the calibration plot are indicative of a good linear relationship between concentration variation and area.

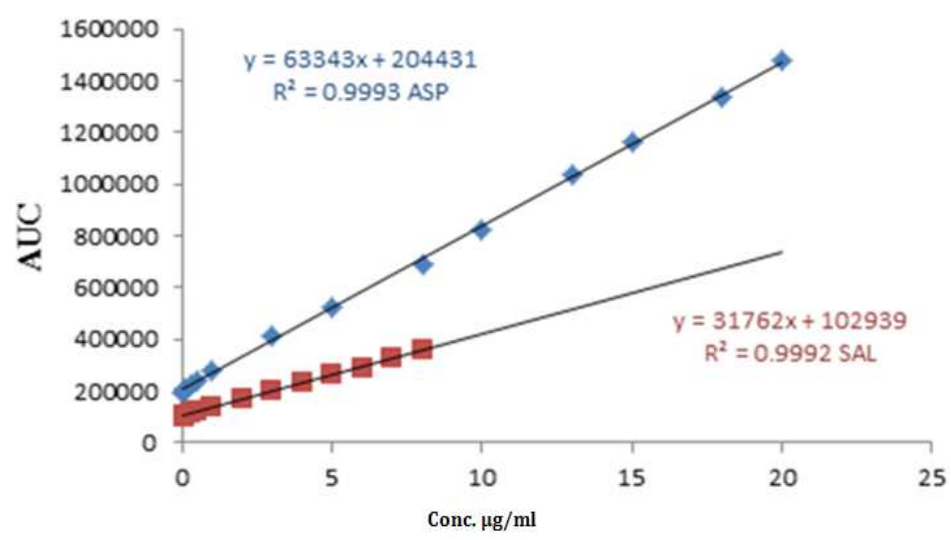

Fig. 5: Calibration graphs of ASP and SAL using HPLC

Table 2: Statistical parameters of HPLC determination of ASP and SAL

\begin{tabular}{lll}
\hline Statistical parameter & Value & Salicylic acid \\
\cline { 2 - 3 } & Aspirin & $\mathrm{y}=31762[\mathrm{X}]+10293$ \\
\hline Linear equation & $\mathrm{y}=63343[\mathrm{X}]+204431$ & 31762 \\
Slope $(\mathrm{m})$ & 63343 & 10293 \\
Intercept $(\mathrm{b})$ & 204431 & 0.9992 \\
Correlation Coefficient $\left(\mathrm{R}^{2}\right)$ & 0.9993 & 99.92 \\
Percentage Linearity $\left(\mathrm{R}^{2} \%\right)$ & 99.93 & 4953 \\
Intercept standard error & 8957 & 14251 \\
Intercept standard deviation & 23794 & 2.21 \\
Relative standard deviation $(\mathrm{RSD})$ & 2.36 & 0.004 \\
LOD $(\mu \mathrm{g} / \mathrm{ml})$ & 0.006 & $0.02-8$ \\
Linearity range $(\mu \mathrm{g} / \mathrm{ml})$ & $0.05-20$ & $111.78>>2.18$ \\
Calculated t-value & $130.87>>2.14$ & \\
\hline
\end{tabular}

\section{Accuracy, precision and recovery of proposed methods}

This study was carried out to assure the closeness of the test results obtained by the analytical method to the true value [15]. For study methods ASP and SAL were determined at three different selected concentrations within the Beer's law limits 10, 15, 20 and 0.3, 1.0, 1.5 $\mu \mathrm{g} / \mathrm{ml}$ for ASP and SAL respectively, using UV-VIS spectrophotometry, while $5,10,15$ and $0.08,0.5,1.0 \mu \mathrm{g} / \mathrm{ml}$ for ASP and SAL respectively by HPLC method. The results were reported as \% Recovery, \% Error and $\%$ RSD, as in table 3, which revealed that the suggested method for detection of aspirin and salicylic acid were interesting and quite convenient with respect to the methods and parameters calculated. 
Table 3: Accuracy and precision of proposed methods

\begin{tabular}{|c|c|c|c|c|}
\hline \multicolumn{5}{|l|}{ UV-VIS } \\
\hline \multicolumn{3}{|c|}{ ASP $(\mu \mathrm{g} / \mathrm{ml}) \%$ recovery } & \multirow{2}{*}{ \%Error } & \multirow[t]{2}{*}{$\%$ RSD (n = 3) } \\
\hline Taken & Mean found $\pm \operatorname{SD}(n=3)$ & & & \\
\hline 10 & $10.06 \pm 0.014$ & 100.06 & 0.06 & 0.14 \\
\hline 15 & $15.13 \pm 0.016$ & 100.87 & 0.13 & 0.11 \\
\hline 20 & $19.96 \pm 0.029$ & 99.80 & 0.20 & 0.15 \\
\hline \multicolumn{5}{|c|}{ SAL $(\mu \mathrm{g} / \mathrm{ml})$} \\
\hline Taken & Mean found $\pm \operatorname{SD}(n=3)$ & & & \\
\hline 0.3 & $0.31 \pm 0.0003$ & 103.33 & 3.33 & 0.10 \\
\hline 1.0 & $1.01 \pm 0.0017$ & 101.00 & 1.00 & 0.17 \\
\hline 1.5 & $1.48 \pm 0.0024$ & 98.67 & 0.33 & 0.16 \\
\hline \multirow{2}{*}{\multicolumn{5}{|c|}{$\begin{array}{l}\text { HPLC } \\
\text { ASP (ug/ml) }\end{array}$}} \\
\hline & & & & \\
\hline Taken & Mean found $\pm \operatorname{SD}(n=3)$ & & & \\
\hline 5 & $4.99 \pm 0.0085$ & 99.80 & 0.20 & 0.17 \\
\hline 10 & $10.02 \pm 0.008$ & 100.20 & 0.20 & 0.08 \\
\hline 15 & $15.19 \pm 0.018$ & 101.26 & 1.26 & 0.12 \\
\hline \multicolumn{5}{|c|}{ SAL $(\mu \mathrm{g} / \mathrm{ml})$} \\
\hline Taken & Mean found $\pm \operatorname{SD}(n=3)$ & & & \\
\hline 0.1 & $0.099 \pm 0.0001$ & 99.66 & 0.34 & 0.10 \\
\hline 0.5 & $0.499 \pm 0.005$ & 99.80 & 0.20 & 0.01 \\
\hline 1.0 & $1.004 \pm 0.0009$ & 100.40 & 0.40 & 0.09 \\
\hline
\end{tabular}

Values represent mean $\pm S D, n=3$.

Table 4: The obtained results of ASP and SAL in pharmaceutical tablets

\begin{tabular}{|c|c|c|c|c|c|c|c|}
\hline \multirow[t]{2}{*}{ Company } & \multirow{2}{*}{$\begin{array}{l}\text { Aspirin weight } \\
\text { (mg) }\end{array}$} & \multicolumn{2}{|c|}{ Mean found of ASP $(\mathrm{mg}) \pm S D(n=3)$} & \multicolumn{2}{|c|}{ \% recovery } & \multicolumn{2}{|c|}{$\%$ salicylic acid \pm SD $(n=3)$} \\
\hline & & UV-VIS & HPLC & UV-VIS & HPLC & UV-VIS & HPLC \\
\hline Cox-pharmaceutical Ltd. & 75 & $74.25 \pm 0.53$ & $74.36 \pm 0.61$ & 99.00 & 99.15 & $0.111 \pm 0.002$ & $0.108 \pm 0.001$ \\
\hline Dijla-IRAQ & 100 & $100.90 \pm 1.78$ & $99.94 \pm 1.45$ & 100.90 & 99.94 & $0.101 \pm 0.001$ & $0.102 \pm 0.001$ \\
\hline Adiphram & 100 & $100.05 \pm 1.04$ & $100.00 \pm 0.99$ & 100.05 & 100.00 & $0.102 \pm 0.001$ & $0.100 \pm 0.002$ \\
\hline SDI-IRAQ & 100 & $99.85 \pm 1.22$ & $100.03 \pm 1.11$ & 99.85 & 100.03 & $0.113 \pm 0.003$ & $0.103 \pm 0.002$ \\
\hline Bristol laboratories Ltd & 75 & $74.5 \pm 0.66$ & $75.01 \pm 0.44$ & 99.33 & 100.01 & $0.101 \pm 0.001$ & $0.102 \pm 0.001$ \\
\hline Wockhardt UK & 300 & $299.4 \pm 1,98$ & $300.04 \pm 1.88$ & 99.80 & 100.01 & $0.123 \pm 0.011$ & $0.121 \pm 0.003$ \\
\hline Aswar alkhaleje-IRAQ & 100 & $101.30 \pm 1.34$ & $99.91 \pm 1.14$ & 101.30 & 99.91 & $0.109 \pm 0.001$ & $0.103 \pm 0.002$ \\
\hline BAYAR & 81 & $80.60 \pm 0.88$ & $81.02 \pm 0.77$ & 99.50 & 100.02 & $0.099 \pm 0.001$ & $0.107 \pm 0.001$ \\
\hline MOH-IRAQ & 100 & $99.80 \pm 0.98$ & $100.21 \pm 0.88$ & 99.80 & 100.21 & $0.099 \pm 0.001$ & $0.095 \pm 0.001$ \\
\hline ATABAY-Turkey & 80 & $82.08 \pm 0.87$ & $80.06 \pm 0.67$ & 102.60 & 100.07 & $0.103 \pm 0.001$ & $0.111 \pm 0.003$ \\
\hline ASIA-Syria & 81 & $81.25 \pm 0.77$ & $81.00 \pm 0.55$ & 100.31 & 100.00 & $0.112 \pm 0.002$ & $0.102 \pm 0.001$ \\
\hline Medcellpharma-Nether. & 100 & $99.05 \pm 1.01$ & $100.15 \pm 0.99$ & 99.05 & 100.15 & $0.109 \pm 0.002$ & $0.108 \pm 0.001$ \\
\hline Pharmaline-Lebanon & 100 & $102.03 \pm 1.35$ & $101.27 \pm 1.21$ & 102.03 & 101.27 & $0.099 \pm 0.001$ & $0.098 \pm 0.001$ \\
\hline Actavis & 300 & $301.80 \pm 1.89$ & $304.54 \pm 1.11$ & 100.60 & 101.51 & $0.120 \pm 0.003$ & $0.119 \pm 0.002$ \\
\hline Antibiotic SA-Romania & 100 & $98.98 \pm 1.02$ & $99.76 \pm 1.03$ & 98.98 & 99.76 & $0.105 \pm 0.001$ & $0.109 \pm 0.002$ \\
\hline Rameda-Egypt & 75 & $74.60 \pm 0.76$ & $74.78 \pm 0.71$ & 99.46 & 99.71 & $0.115 \pm 0.002$ & $0.116 \pm 0.002$ \\
\hline BAYAR & 100 & $100.01 \pm 1.12$ & $100.65 \pm 1.01$ & 100.01 & 100.65 & $0.100 \pm 0.001$ & $0.099 \pm 0.001$ \\
\hline Sunlond-Atlanta & 81 & $81.09 \pm 0.81$ & $80.91 \pm 0.76$ & 100.11 & 99.89 & $0.112 \pm 0.002$ & $0.101 \pm 0.001$ \\
\hline Cisphrama-USA & 81 & $80.95 \pm 0.75$ & $80.25 \pm 0.66$ & 99.93 & 99.07 & $0.099 \pm 0.001$ & $0.101 \pm 0.002$ \\
\hline Allegiant Health & 81 & $80.64 \pm 0.73$ & $81.23 \pm 0.72$ & 99.55 & 100.28 & $0.113 \pm 0.002$ & $0.111 \pm 0.003$ \\
\hline
\end{tabular}

Values represent mean $\pm S D, n=3$.

Table 5: The amount of heavy metals measured by AAS

\begin{tabular}{|c|c|c|c|c|c|c|}
\hline Company & $\begin{array}{l}\text { Pb found at } \\
283 \mathrm{~nm}(\mu \mathrm{g} / \mathrm{kg}) \mathrm{n} \\
=3\end{array}$ & $\begin{array}{l}\text { Co found at } \\
210 \mathrm{~nm} \\
(\mu \mathrm{g} / \mathrm{kg}) \mathrm{n}=3\end{array}$ & $\begin{array}{l}\text { Fe found at } \\
248 \mathrm{~nm} \\
(\mu \mathrm{g} / \mathrm{kg}) \mathrm{n}=3\end{array}$ & $\begin{array}{l}\text { Ni found at } \\
232 \mathrm{~nm} \\
(\mu \mathrm{g} / \mathrm{kg}) \mathrm{n}=3\end{array}$ & $\begin{array}{l}\text { Cd found at } 228.8 \\
\mathrm{~nm}(\mu \mathrm{g} / \mathrm{kg}) \mathrm{n}=3\end{array}$ & $\begin{array}{l}\text { Cr found at } 357.9 \\
\mathrm{~nm}(\mu \mathrm{g} / \mathrm{kg}) \mathrm{n}=3\end{array}$ \\
\hline Cox-pharmaceutical Ltd. & 12.1 & 1.2 & 12.1 & 6.2 & 8.9 & 6.2 \\
\hline Dijla-IRAQ & 7.2 & 1.4 & 12.2 & 6.5 & 7.2 & 6.5 \\
\hline Adiphram & 10.4 & 1.2 & 10.4 & 7.2 & 8.3 & 7.2 \\
\hline SDI-IRAQ & 10.5 & 1.3 & 10.5 & 5.4 & 7.8 & 5.4 \\
\hline Bristol laboratories Ltd. & 10.6 & 1.1 & 10.6 & 3.8 & 8.8 & 3.8 \\
\hline Wockhardt UK & 7.5 & 1.3 & 9.5 & 5.5 & 7.5 & 5.5 \\
\hline Aswar alkhaleje-IRAQ & 7.8 & 1.4 & 9.8 & 4.6 & 7.8 & 4.6 \\
\hline BAYAR (81) & 10.0 & 0.9 & 10.0 & 3.2 & 3.5 & 3.2 \\
\hline MOH-IRAQ & 10.2 & 1.1 & 10.2 & 5.1 & 8.4 & 5.1 \\
\hline ATABAY-Turkey & 10.8 & 1.5 & 10.8 & 5.6 & 5.6 & 7.6 \\
\hline ASIA-Syria & 10.9 & 1.4 & 10.9 & 6.6 & 7.7 & 6.6 \\
\hline Medcellpharma-Nether. & 6.9 & 1.2 & 9.9 & 4.6 & 6.9 & 4.6 \\
\hline Pharmaline-Lebanon & 11.3 & 1.3 & 11.3 & 3.6 & 5.3 & 3.4 \\
\hline Actavis & 8.6 & 1.0 & 8.6 & 6.3 & 8.6 & 6.3 \\
\hline Antibiotic SA-Romania & 12.0 & 1.4 & 12.0 & 6.7 & 8.8 & 7.6 \\
\hline Rameda-Egypt & 6.7 & 1.2 & 9.7 & 5.8 & 2.6 & 5.8 \\
\hline BAYAR (100) & 10.3 & 1.3 & 10.3 & 2.3 & 4.4 & 2.3 \\
\hline Sunlond-Atlanta & 8.4 & 1.0 & 8.4 & 2.1 & 8.4 & 2.4 \\
\hline Cisphrama-USA & 8.1 & 1.0 & 8.1 & 2.3 & 8.1 & 2.2 \\
\hline Allegiant Health & 10.7 & 1.1 & 10.7 & 3.4 & 6.7 & 2.3 \\
\hline
\end{tabular}

Values represent mean only $\mathrm{n}=3$. 


\section{Quantitative assessment of ASP and SAL in tablets}

Twenty pharmaceutical drugs that contain aspirin were commercially available in Iraqi markets. In table 3 , we mentioned the names of the companies that we used their products to detect aspirin and salicylic acid. Table 4, represents the data we was obtained from our recommended and suggested method. Interestingly the results were suggested the precision and the appropriateness of the suggested method to determine of ASP and SAL in pharmaceutical tablets. Furthermore, the data were revealed that the recovery percentages for applying methods are with an acceptable range of the medication samples and the amount of the salicylic acid was within the standard and accepted percentage as compared to official analytical method $[16,17]$. Therefore, we used recovery percentage in formulating tablets as indicating the validity of the method for analysis the aspirin and the impurities of salicylic acid in pharmaceutical formulation. RSD for all results is less than $2 \%$.

\section{Atomic absorption spectrophotometry}

The heavy metals contain in aspirin tablets, such as Nickel, Cobalt, Iron, Lead, Cadmium and Chromium ions were determined by atomic absorption spectrophotometry. We summarized the results in table 5. Interestingly the data reveal that the amount of these metals within the normal ranges adopted by WHO [18].

\section{CONCLUSION}

The developed analytical methods were found to be simple, sensitive, rapid, economical, linear, reproducible and applicable over a wide concentration range with high precision and accuracy. The method was found suitable to determine the concentration of ASP as well as in the dosage form analysis precisely and accurately. The sample recovery from the formulation by using this method was very applicable in respect to its label claim. The results of the validated parameters were found to be satisfactory and can also be applied for the quality control tool in the estimation of aspirin, salicylic acid and heavy metal ions in pharmaceutical dosage forms.

\section{ACKNOWLEDGEMENT}

The author would like to express his gratitude to the University of Diyala, College of Education for Pure Science, Department of chemistry for providing lab and research facilities to complete this work.

\section{AUTHORS CONTRIBUTIONS}

All the author have contributed equally

\section{CONFLICT OF INTERESTS}

\section{Declared none}

\section{REFERENCES}

1. Muchtaridi M, Yuliani E, Sopyan I. Application off-line SPEHPLC/UV methods in the analysis in human (in vitro). Int J Pharm Pharm Sci 2015;8:255-61.

2. Khan HN, Bandewar SS, Zameeruddin M, Bharkad VB. Development and validation of RP-HPLC method for simultaneous determination of aspirin and omeprazole. Der Pharm Chem 2017;9:55-8.

3. Kumar SS, Jamadar DL, Bhat K, Prashant B, Musmade B, Vasantharaju SG, et al. Analytical method development and validation for aspirin. Int J ChemTech Res 2010;2:389-99.

4. Pawar PY, Ankita R, Lokhande BR, Bankar AA. Simultaneous estimation of atorvastatin calcium and aspirin in pure and capsule dosage form by using UV spectrophotometric method. Der Pharm Chem 2013;5:98-103.

5. Bae SK, Seo KA, Jung EJ, Kim HS, Yeo CW, Shon JH, et al. Determination of acetylsalicylic acid and its major metabolite, salicylic acid, in human plasma using liquid chromatographytandem mass spectrometry: application to pharmacokinetic study of astrix ${ }^{\circledR}$ in Korean healthy volunteers. Biomed Chromatogr 2008;22:590-5.

6. US Food and Drug Administration. Guidance for Industry, Q3A Impurities in New Drug Substances; 2003.

7. US Food and Drug Administration. Guidance for Industry, Q3B Impurities in New Drug Products; 2006.

8. Desai NC, Senta RD. Simultaneous RP-HPLC determination of salicylamide, salicylicacid and deferasirox in the bulk API dosage forms. JTUSCI 2015;9:245-51.

9. Acheampong A, Addai-Arhin S, Apau J, Gyasi WO. Development and validation of a RP-HPLC method with PDA detection for the simultaneous estimation of acetylsalicylic acid, paracetamol and caffeine in fixed dose combination tablets. Int J Chem Biomol Sci 2015;1:211-7.

10. Patila AS, Khairnara BJ, Maneb DV, Chaudharia BR. A validated stability-indicating HPLC related substances method for salicylic acid in bulk drug and dosage form. World J Pharm Sci 2015;3:1184-90.

11. Gousuddin MD, Sengupta P, Tripathi VD, Das A. Stability indicating RP-HPLC method for simultaneous determination of aspirin and clopidogrel in dosage form. MJAS 2016;20:247-57.

12. Hullah Bhuyian MD, Rashid DH, Islam AF, Tareque MD. Development and validation of method for determination of clobetasol propionate and salicylic acid from pharmaceutical dosage form by HPLC. BJPR 2015;7:375-85.

13. Skoog DA, Holler FJ, Crouch SR. Instrumental analysis. $11^{\text {th }}$ ed. Delhi: Cengage Learning India Pvt Ltd; 2012.

14. Huber L. Validation of analytical methods and processes. In: The Pharmaceutical codex, principles and practice of pharmaceutics. $12^{\text {th }}$ ed. London: The Pharmaceutical Press; 1994. p. 507-24.

15. Davidson AG. Ultraviolet-visible absorption spectrophotometry. In: Beckett AH, Stenlake JB. editors. Practical pharmaceutical chemistry. $4^{\text {the }}$. Part 2. New Delhi: CBS Publishers and distributors; 2002. p. 275-337.

16. Ahmed MS, Noor QA. Simultaneous spectrophotometric determination of aspirin and codeine. Res J Pharm Biol Chem Sci 2017;8:1137-43.

17. Salako Q, Fadiran EO, Thomas WO. Detection and determination of salicylic acid impurity in aspirin tablet formulation by HPLC. Afr J Med Med Sci 1989;18:215-8.

18. Somaya ST, Khairi SA, Abdussalam SA, Mohammad MK. Atomic absorption analysis of toxic heavy metal impurities in various commercial aspirin formulations. AB 2015;3:9-14. 